\title{
Elements of the teacher development system in learning management according to the concept of Education 4.0
}

\author{
Jedsada Janpleng ${ }^{1}$, Karn Ruangmontri ${ }^{2}$ \\ ${ }^{1}$ Ed.D. candidate in Educational Administration and Development, Faculty of Education, \\ Mahasarakham University, Thailand \\ ${ }^{2}$ Faculty of Education, Mahasarakham University, Thailand
}

\begin{tabular}{l}
\hline \hline Article Info \\
\hline Article history: \\
Received July 6, 2021 \\
Revised August 20, 2021 \\
Accepted September 13, 2021
\end{tabular}

Keywords:
basic education
Education 4.0
learning management
professional development
teacher development

\begin{abstract}
The purpose of this study was to study the elements of the teacher development system in learning management according to the concept of Education 4.0 with a professional learning community process in secondary schools under the Office of the Basic Education Commission by studying the components of the teacher development system in learning management according to the concept of education 4.0 with a professional learning community process from 7 experts, consisting of 1) two people in higher education administration, 2) one person who has a stake in learning management, 3) two school directors, and 4) two teaching specialist teachers. The sample group was obtained by using a specific selection method using the teacher development system component assessment in learning management according to the concept of education 4.0 with a professional learning community process in secondary schools, under the Office of the Basic Education Commission, which is a 5-level rating scale. System Components Teacher development in learning management According to the educational model 4.0 with a professional learning community process in secondary schools, under the Office of the Basic Education Commission, there are 4 main components, 13 subcomponents, namely; 1) The inputs consist of (1) executives, (2) learning management courses, (3) teachers, (4) resources that support learning management. 2) The process consists of (1) Identifying challenging problems, (2) Concept finding stage, (3) Planning and development stage, (4) Testing and evaluation stage, (5) Presenting results to society. 3) Productivity consists of (1) Teachers have knowledge and understanding of learning management, (2) Teachers are competent in learning management. 4) feedback, which consists of (1) reporting on results and (2) improvements, corrections, and developments. And, the experts assess the suitability of the elements at a high and highest level and have consistent opinions on all components..
\end{abstract}

This is an open access article under the CC BY-SA license.

\author{
Corresponding Author: \\ Jedsada Janpleng \\ Department of Educational Administration and Development, \\ Faculty of Education, \\ Mahasarakham University \\ Thailand \\ Email : Jedsada.j@ln.ac.th
}

\section{INTRODUCTION}

In today's era, it is known that each class will have students with different and diverse abilities, as the Second Education Reform (2009-2018) seeks to address the problem of quality improvement. teachers to provide teachers with sufficient competence to develop the quality of modern Thai people. Because teachers are important personnel of education and are involved in social development, teachers are responsible for teaching and learning to educate and develop the quality of learners until they can communicate ideas, solve problems, use technology, 
and have life skills, including morality, ethics, discipline, patriotism (Panich, 2012). Entering Thailand 4.0, Thailand must create its innovations without relying on foreigners as before, which is the main goal of Thailand 4.0. Driving towards becoming a country "Prosperous, Stable, and Sustainable" is to make Thailand move towards a high-income country with high-quality human resource development (Phisitpaiboon, 2016).

Nowadays, teachers and educators need to be knowledgeable and competent to be able to drive the educational reform process, especially the continuous and serious learning reform (Office of the National Education Commission, 2000). Improving the quality of education has resulted in numerous studies confirming that having teachers with the right knowledge, skills, and preparing new teachers for good performance directly affects student achievement (Darling-Hammond, 1996; Brookfield, 1995). There is a fundamental belief that we want to help and encourage school personnel to exchange knowledge with each other through the process of professional development (Wells \& Feun, 2007). which the development of competence and competence must cover the development of both teachers and school administrators, if school administrators see the value and support the professional learning community as a tool to develop teacher learning management, and learning of students as well (Vescio et.al., 2006).

The result is an opportunity for teachers and school administrators to participate in thinking, jointly solving problems, and making decisions together within the school, and the important mission of the school's professional learning community focuses on developing teacher competency and Executives for the development of student learning (Hord, 2004). The learning of the students will be achieved through analytical thinking and action. Students should be the center of teaching, while the teacher plays a role in training, guiding, preparing, and facilitating. (Ploykornburi, 1998). The adoption of the professional learning community concept in schools is a tool of change in teacher behavior influenced by dialogue to facilitate professional development among school teachers (Gilrane, 2008).

The relationship between the shared efficiency of teachers and the professional learning community results in better student performance (Calcasola, 2013). Running a professional learning community is also an opportunity for professional advancement (Morrow, 2010). This means that professional learning communities are constantly transforming students, teachers, administrators and schools (Panich, 2012). The professional learning community helps to develop teachers. causing teachers to work together to take responsibility for student learning to have higher academic achievement as well as sharing teaching methods that clearly see results by participating in critical discussions about their teaching problems to seek advice from colleagues (DuFour \& Mattos, 2013). The professional learning community of teachers exchanging or sharing the role of a mentor, advisor, or specialist, leading to practical guidance to improve teaching and relationships within the school. In addition, teachers engage in discussions to reflect on student teaching and learning practices, enabling teachers to understand the teaching process and to monitor the quality of teacher performance and student learning (Stoll et al., 2006).

This is consistent with the study by Noparak et.al. (2014), the creation of a professional learning community enables teachers to conduct education in the development of teaching and learning, and the development of institutional curricula and learning management in a professional learning community will enable effective classroom teacher teaching and student success. Learning success leads to qualitative changes in both the teacher's profession and student achievement (Elmore, 2002; Lewis \& Andrews, 2004). From the study conducted in the form of a professional learning community, the results were good for both the teaching profession and the learner. In other words, the positive effect on teachers found that the professional learning community affected teachers, which reduced teachers' feelings of loneliness in teaching, increased feelings of commitment to school missions and goals, and increased enthusiasm to act. to achieve the mission so vigorously that Want to share, learn and take responsibility for the overall development of students. These are regarded as "learning powers" which result in better classroom teaching practices and teachers have also found progress in adapting learning management methods following learner characteristics. clearly.

As for the positive effect on the learners, it was found that the professional learning community affected the learners, that is, the learners had significantly increased learning outcomes. (Chookamnerd \& Sungtong, 2014). From the study of teacher professional development and teacher development factors at present, it was found that teachers have developed quite a lot, but the lack of monitoring and evaluation of the application of knowledge to develop teaching and learning management causes redundancy in the substance. of teacher training courses and training does not meet the needs of teachers undergoing development (Education Council Secretariat, 2015). The development of teachers in the past cannot really solve the problem of learning management.

Most of the operations are carried out following the policy of the parent agency, not due to the real needs of the teachers. In addition, teacher development lacks holistic development or integration, does not encourage teachers to exchange knowledge together, teachers have a lot of workloads, the teacher development budget is limited. From the survey of teachers' needs, it was found that teachers needed a system of teaching and learning, and a sample of the results of the study on solving learners' problems, wanting to develop techniques for learning management according to their potential and differentiation. Differences between individuals, problem-solving, real-world assessments, education development, learners ready to be put into practice. 
Therefore, it is imperative to seek new methods of teacher development. This is because learning management is unique. It is a science in both content and teaching techniques. Therefore, continuous development is required to be successful. For this reason, the students studied the elements and necessities of the teacher development system in learning management in the field of learning management according to the concept of education 4.0 with a professional learning community process in secondary schools, under the Office of the National Education Commission. Basic education can be used to develop a system for teacher development in learning management in terms of quality learning management for effective and efficient learning management in educational institutions.

\section{METHOD}

A study of the elements and necessities of the teacher development system in learning management according to the Education 4.0 concept with the professional learning community process in secondary schools under the Office of the Basic Education Commission (Figure 1). There are steps to do as follows; information.

1. Study-related documents and studies, analyze, synthesize, categorize concepts, relevant background

2. Develop a conceptual framework for teacher development system in learning management according to the concept of education 4.0 with a professional learning community process, by using the results from the study of related study documents to create a conceptual framework for teacher development system in Manage learning according to the concept of Education 4.0.

3. To study the opinions of experts regarding the components and steps of the teacher development system in the management of learning according to the concept of education 4.0 with a professional learning community process in secondary schools under the Office of the Basic Education Commission.

The researchers created a questionnaire to ask the opinions of experts to find the System Components using the questionnaire and study the needs and requirements of the teacher development system in the management of learning based on the concept of education. 4.0 with a professional learning community process from all 333 target groups using questionnaires.

Population and sample: (1) The study of the components of the teacher development system in learning management according to the educational concept of 4.0 with a professional learning community process was used by seven experts, consisting of 1) Higher education administration, 2 people. 2) One person who has a stake in learning management. 3) Director of the educational institute, 2 people. 4) Two teaching specialist teachers. They have come up with a specific method of choice. (2) The study of necessity, teacher development system in learning management according to the concept of education 4.0 with the process of the professional learning community, used in secondary schools of the Office of the Basic Education Commission of 111 schools. The data providers consisted of school administrators, teachers, academic supervisors, and teachers totaling 333 people, which were obtained by Multi-stage Random Sampling.

4. Analyze and synthesize the data from the questionnaire. To draft a system for developing teachers to manage learning based on the Education 4.0 concept with a professional learning community process, which analyzes the opinions of experts obtained from the creation of a questionnaire to verify the System Components. The data obtained from the feedback questionnaire were created to determine the system's needs using the mean score and standard deviation statistics. 


\begin{tabular}{|c|c|c|c|c|c|c|c|}
\hline \multicolumn{8}{|c|}{$\begin{array}{c}\text { Principles, Concepts, Theories } \\
\end{array}$} \\
\hline $\begin{array}{l}\text { System } \\
\text { Components; } \\
\text { 1) Import factors } \\
\text { 2) Process } \\
\text { 3) Productivity } \\
\text { 4) Feedback }\end{array}$ & \multicolumn{2}{|c|}{$\begin{array}{l}\text { System development } \\
\text { process; } \\
\text { 1) Study and analyze } \\
\text { 2) Design and check } \\
\text { 3) Trial and } \\
\text { Evaluation }\end{array}$} & \multicolumn{3}{|c|}{$\begin{array}{l}\text { Learning management according } \\
\text { to the concept of Education } 4.0 ; \\
\text { 1. Identify challenging problems } \\
\text { 2. Search for ideas } \\
\text { 3. Planning and Development Stage } \\
\text { 4. Testing and Evaluation } \\
\text { 5. Stage of presenting results to } \\
\text { society }\end{array}$} & \multicolumn{2}{|c|}{$\begin{array}{l}\text { Professional learning } \\
\text { community; } \\
\text { 1) Having shared values and } \\
\text { vision } \\
\text { 2) Exchange of operations } \\
\text { between people } \\
\text { 3) Mutual support and } \\
\text { leadership } \\
\text { 4) Teams join forces }\end{array}$} \\
\hline \multirow{2}{*}{\multicolumn{8}{|c|}{$\begin{array}{l}\text { Draft: Teacher development system in learning management according to the concept of education } 4.0 \text { with a } \\
\text { professional learning community process in secondary schools, under the Office of the Basic Education } \\
\text { Commission }\end{array}$}} \\
\hline Input & & & & & & & \\
\hline \multicolumn{2}{|c|}{$\begin{array}{l}\text { 1) Executives } \\
\text { 2) Learning Management } \\
\text { Course } \\
\text { 3) Teachers } \\
\text { 4) Resources that support } \\
\text { learning } \\
\text { 5) Environment }\end{array}$} & \multicolumn{3}{|c|}{$\begin{array}{l}\text { Process } \\
\text { 2) Identifying challenging problems } \\
\text { 3) Planning and development stage } \\
\text { 4) Testing and evaluation } \\
\text { 5) The stage of presenting the results } \\
\text { to society }\end{array}$} & \multicolumn{3}{|c|}{$\begin{array}{l}\text { Productivity Teachers have knowledge and } \\
\text { understanding of learning management. } \\
\text { 2) Teachers can manage to learn. } \\
\text { 3) Teachers are satisfied with learning } \\
\text { management. }\end{array}$} \\
\hline \multicolumn{8}{|c|}{ Professional learning community } \\
\hline \multicolumn{2}{|c|}{$\begin{array}{c}\text { Shared values and } \\
\text { vision }\end{array}$} & \multicolumn{2}{|c|}{$\begin{array}{l}\text { Exchange of work between } \\
\text { people }\end{array}$} & \multicolumn{3}{|c|}{$\begin{array}{c}\text { Shared Support and } \\
\text { Leadership }\end{array}$} & Teamwork together \\
\hline \multicolumn{2}{|c|}{$\begin{array}{l}\text { 1) Having values and } \\
\text { vision for learners' } \\
\text { learning } \\
\text { 2) Having values and } \\
\text { vision for working } \\
\text { together among personnel }\end{array}$} & \multicolumn{2}{|c|}{$\begin{array}{l}\text { 1) Good practice learning } \\
\text { exchange } \\
\text { 2) Learning and professional } \\
\text { development } \\
\text { 3) Aesthetic conversation to } \\
\text { reflect the results of the } \\
\text { practice }\end{array}$} & \multicolumn{2}{|c|}{$\begin{array}{l}\text { 1) Power-sharing } \\
\text { 2) Participation in } \\
\text { decision making } \\
\text { 3) Promotion of } \\
\text { Leadership } \\
\text { Development }\end{array}$} & & $\begin{array}{l}\text { 1) Learning and } \\
\text { 2) Apply knowledge } \\
\text { 3) Together to be a good } \\
\text { community }\end{array}$ \\
\hline
\end{tabular}

Figure 1 Theoretical framework

\section{RESULT AND DISCUSSION}

A study of the elements and necessities of the teacher development system in learning management according to the Education 4.0 concept by the professional learning community process in secondary schools under the Office of the Basic Education Commission are as follows. The results of the analysis of data from concepts, theories, principles, and research related to the teacher development system in learning management according to the study concept of 4.0 with professional learning community process, it was found that the results of the knowledge analysis on the development of teacher development system in learning management according to the concept of education 4.0 with the professional learning community process, as shown in the Table 1 .

Table 1 Professional learning community concept in learning management

\begin{tabular}{|l|l|c|c|c|}
\hline Main component & \multicolumn{1}{|c|}{ Sub-components } & $\overline{\mathrm{x}}$ & \multicolumn{1}{|c|}{ S.D. } & Suitability level \\
\hline \multirow{5}{*}{ 1. Input } & 1. Executives & 4.46 & 0.32 & High \\
\cline { 2 - 5 } & 2. Learning Management Course & 4.60 & 0.36 & Highest \\
\cline { 2 - 5 } & 3. Teachers & 4.63 & 0.38 & Highest \\
\cline { 2 - 5 } 2. Process & 4. Support Resources & 4.60 & 0.55 & Highest \\
\cline { 2 - 5 } & 1. Identifying challenging problems & 4.55 & 0.37 & Highest \\
\cline { 2 - 5 } & 2. The concept search stage & 4.64 & 0.38 & Highest \\
\cline { 2 - 5 } & 3. Planning and Development Stage & 4.68 & 0.39 & Highest \\
\cline { 2 - 5 } 3. Productivity & 4. Testing and Evaluation & 4.60 & 0.38 & Highest \\
\cline { 2 - 5 } & 5. Stage of presenting results to society & 4.60 & 0.40 & High \\
\hline
\end{tabular}




\begin{tabular}{|c|c|c|c|c|}
\hline Main component & Sub-components & $\overline{\mathrm{x}}$ & S.D. & Suitability level \\
\hline & $\begin{array}{l}\text { 2. Teachers have the ability to manage } \\
\text { learning. }\end{array}$ & 4.60 & 0.54 & Highest \\
\hline \multirow[b]{2}{*}{ 4. Feedback } & 1. Reporting results & 4.60 & 0.43 & Highest \\
\hline & $\begin{array}{l}\text { 2. Improvements, corrections, and } \\
\text { developments }\end{array}$ & 4.80 & 0.44 & Highest \\
\hline
\end{tabular}

From Table 1, it was found that the appropriateness of the components of the teacher development system in learning management according to the concept of education 4.0 with the professional learning community process in secondary schools under the Office of the Basic Education Commission was at the high and highest level.

This is in line with Bertalanffy (1993) who introduced the concept of system components consist of four components: 1) Inputs or Receptors refers to what is required to operate a system that presents the concept of System. There are 4 components which are 1) Receptors, 2) Process, 3) Effectors and 4) Feedback that is processed in a self-defense and self-control manner to maintain system balance. Consistent with Thongnoi (2013) who studied the development of an effective academic administration system in elementary schools found that the developed academic administration system consists of 4 aspects. These are inputs, processes, outputs, and feedback (Uttaramart, 2011). The development of a performance appraisal system for secondary school teachers under local administrative organizations. The performance appraisal system of secondary school teachers under the local administrative organization consists of four aspects: inputs, processes, outputs, and feedback (Boonmak, 2015). Teacher development system in the field of school learning management to expand educational opportunities consists of four aspects: input, process, output, feedback (Phu-aram, 2017; Thongsuk et.al., 2020).

\section{CONCLUSION}

Components for teacher development in learning management according to the concept of education 4.0 with the professional learning community process found that the experts gave useful advice, in which the researcher took the recommendations and analyzed them into 4 main components, 13 sub-components that is consistent. Teacher development in learning management according to the educational model 4.0 with a professional learning community process in secondary schools, under the Office of the Basic Education Commission, there are 4 main components, 13 subcomponents.

\section{ACKNOWLEDGEMENT}

I would like to thank all the teachers and experts who have kindly considered the quality of research tools. Please be interviewed. Assessment confirms the composition. assess suitability possibility and the benefits of development of teacher development system in learning management Based on education 4.0 concept with professional learning community process in secondary school under the Office of the Basic Education Commission I would like to thank the school administrators and teachers for being a sample group for answering the exam and providing useful information until it was successful. I would like to thank all those who sponsored and promoted the scholarship for education. Value and benefits of this thesis The researcher would like to pay homage to his father, mother, burapha teachers, as well as all benefactors.

\section{REFERENCES}

Bertalanffy, L. V. (1993). An outline of general systems theory. Holt, Rinehart, and Winston.

Boonmak, T. (2015). Developing a teacher development system in school learning management, expanding educational opportunities. Ed.D. Dissertation, Mahasarakham University.

Brookfield, S. D. (1995). Becoming a critically reflective teacher. Jossey-Bass Publishers.

Calcasola, S. L. (2013). Nursing management: patients with complications from heart disease. Lippincott Williams \& Wlikins.

Chookamnerd, W., \& Sungtong, E. (2014). Professional learning community of in school for teacher professional development based on learner-centered approach. Academic Services Journal Prince of Songkla University, 25(2), 93-102.

Darling-Hammond, L. (1996). What matters most: A competent teacher for every child. Phi Delta Kappan, 73(3), 193.

DuFour, R., \& Mattos, M. (2013). Improve schools. Educational Leadership, 70(7), 34-39.

Education Council Secretariat. (2015). Learning reform Project to Learners (2014-2017) “Reflecting problems and solutions, answering the needs of Thai education reform. Bangkok: Office of the Education Council Secretariat.

Elmore, R. M. (2002). Bridging the gap between standards and achievement: The imperative for professional development in education. The Albert Shanker Institute. 
Gilrane, C. P., Roberts, M. L., \& Russell., L. A. (2008). Building a community in which everyone teaches, learns and reads: A case study. The Journal of Educational Research, 101(6), 333-351.

Hord, S. M. (2004). Learning together, leading together: Changing schools through professional learning communities. Teachers College Press.

Morrow, J. R. (2010). Teachers' perceptions of professional learning communities as opportunities for promoting professional growth. Doctoral Dissertation. North Carolina: Appalachian State University, Boone NC.

Noparak, S. et al. (2014). School-based teacher and school administrator development model in small schools: A case study of Phitsanulok province. Naresuan University.

Office of the National Education Commission. (2000). Presentation of an operational research model for schoolbased primary school teacher development. Bangkok: Office of the National Education Commission.

Panich, V. (2012). Ways to create learning for students in the 21st century. Bangkok: Publication.

Phisitpaiboon, S. (2016). Driving Thai education to Thailand 4.0. Retrieved December 5, 2020 , from http://www.thaihealth.or.th/Content/33499\%- Driving Thai education to \% Thailand\% 204.0.html

Phu-aram, N. (2017). Development of a learning management system using a professional learning community for a network of small primary schools. Ed.D. Dissertation: Mahasarakham University.

Ploykornburi, V. (1998). Learning reform issues, In Education reform, concepts and principles under the National Education Act 1999. Bangkok: Winyoochon Printing House.

Stoll, L., Bolam, R., McMahon, A., Wallance, M., \& Thomas, S. (2006). Professional learning communities: A review of the literature. Journal of Education Change, 7, 221-258.

Thongnoi, N. (2 013 ). Developing an effective academic administration system in primary schools. E.D. Dissertation : Mahasarakham University.

Thongsuk, K., \& Rueangmontri, K. (2020). Program development of ethical leadership enhancement for school administrators under the Office of Basic Education Commission. International Journal of Psychosocial Rehabilitation, 24(1), 2134-2139.

Uttaramart, S. (2011). Development of a performance appraisal system for secondary school teachers under local administrative organizations. E.D. Dissertation : Mahasarakham University.

Vescio, T. K., Gervais, S. J., Heidenreich, S., \& Snyder, M. (2006). The effects of prejudice level and social influence strategy on powerful people's responding to racial out-group members. European Journal of Social Psychology, 36(4), 435-450.

Wells, C., \& Feun, L. (2007). Implementation of learning community principles: A study of six high schools. NASSP Bulletin, 91(2), 141-160. 